\title{
ANÁLISIS DEL DISCURSO POPULISTA EN LA ESPAÑA ACTUAL ${ }^{1}$
}

\author{
JaVIER DE SANTIAgo GuerVós \\ Universidad de Salamanca
}

La ciencia tiende a etiquetar fenómenos recurrentes. Cuando existe una serie de coincidencias en un determinado comportamiento, cuando existen elementos comunes coincidentes en el estudio de la historia, la política, la química, la medicina, la psicología, la sociología, la biología, la antropología, etc., cuando se repiten síntomas o reacciones, entonces puede establecerse un diagnóstico, puede crearse una etiqueta que describe y simplifica el fenómeno que lo caracteriza. En el caso que nos ocupa, en determinadas circunstancias históricas, se producen reacciones políticas que tienen características discursivas comunes. Así, por ejemplo, en una situación de crisis social, el pueblo se presenta como víctima de una fuente de mal de la que solo es posible liberarse por la intercesión de un líder carismático. Esta secuencia, esta conjunción de características da como resultado una técnica discursiva dentro del lenguaje político que se ha definido como populismo.

Quien protagoniza este tipo de discurso se presenta como alguien que va a devolver el poder secuestrado por las élites a los ciudadanos y promete una mejor forma de democracia en la que la participación ciudadana reemplace el manejo de lo público por élites partidistas. La desviación de estos objetivos primarios provocará la contaminación de la palabra y su uso y abuso como instrumento de desacreditación política, tal como se puede observar ya en

${ }^{1}$ Este trabajo ha sido realizado dentro del proyecto I+D Emoción y lenguaje en acción: la función discursiva emotiva/evaluativa en distintos textos y contextos dentro del mundo del trabajo: proyecto persuasión. FFI2013-47792-C2-2-P.

AnMal, XXXIX, 2016-2017, págs. 115-141 
la nueva edición del diccionario de la $R A E^{2}$ (2014) y en casi cualquier aparición del término en la vida política. El populismo se sienta junto a la demagogia, la improvisación, la irresponsabilidad, los enunciados vacíos, los extremos, la revolución, la antidemocracia, la manipulación, la complacencia hacia el pueblo, la xenofobia, el fascismo ${ }^{3}$, etc.

No deja de ser irónico que un politólogo español devenido en político llegue a América Latina para legitimar el propio vocablo «populismo» y, más aun, para sugerir que adoptará algunos de esos rasgos. Habrá que ver que hace con el término una vez de regreso por Europa, donde ser populista quiere decir ser bastante xenófobo, racista y algo nostálgico del fascismo (H. E. Schamis, El País, 5-10-2104).

El vicesecretario de Organización del PP, Carlos Floriano, ha arremetido, en referencia a Podemos, contra el «populismo bolivariano de telepredicador» que quiere «subvertir la democracia» (Público, 11-07-2014).

Populismo es dar a la gente lo que de manera inmediata, emocional y simple quiere [...]. El populismo actual antidemocracia indirecta es antigubernamental, por eso es también anti-PSOE. Y a él se añade, imparable, un nuevo tema populista: la desigualdad (El País, 18-02-2104).

Estas elecciones han puesto de manifiesto que los charlatanes del artefacto populista venden humo tanto como quienes tratan de convencernos de que somos tan sólo unas décimas de déficit (I. Lozano [UPyD], El País, 28-05-2014).

Está claro que trata de salir del eje tradicional derecha/izquierda, pero no deja de dar motivos para pensar que se trata de populismo, entendido como la estrategia política que enfrenta al pueblo con las instituciones, aunque estas sean democráticas.

\section{$[\ldots]$}

Por lo demás, nadie puede atribuirse el papel de vigilante de la ética general como si estuviese dotado de un poder superior. Todo suena a lo mismo: personalismo, populismo, manipulación (El País, Editorial, 19-10-2014).

Patrick Charaudeau ${ }^{4}$ estudia el populismo como un discurso, independientemente del programa político de quien lo usa y del uso político que puede hacerse de la palabra; lo estudia como una técnica discursiva dentro del lenguaje

${ }^{2}$ «Tendencia política que pretende atraer a las clases populares»; añade que se emplea con sentido despectivo.

3 J. de Santiago Guervós. «La relexicalización en el discurso político actual: el ejemplo de populismo a través de la prensa española», en Boletín de la Real Academia Española (BRAE), Tomo XCV, cuaderno CCCXII, junio-diciembre, 2015, págs. 471-500.

${ }_{4}^{4}$ Reflexiones para el análisis del discurso populista», Discurso \& Sociedad, 3/2, 2009, págs. 253-279, y «Réflexions pour l'analyse du discours populiste», Mots, no. 97, Les collectivités territoriales en quête d'identité, ENS Éditions, Lyon, 2011, págs. 101-116. 
político, de ahí que tenga numerosas concomitancias con el lenguaje político en general y de ahí que llegue a afirmar que el populismo y sus estrategias discursivas son las de todo discurso político pero gobernadas por el descontrol y el exceso. Desde nuestro punto de vista, al menos en el caso español, no se trata tanto de una cuestión de excesos discursivos, que los hay, como de acumulación de marcas discursivas. Es una cuestión de grados; un uso puntual frente a un uso continuado de argumentos que tienen en las reclamaciones del pueblo su objetivo fundamental, pero que sigue siendo discurso políticos.

A pesar de la diversidad de objetivos políticos que persigue el populismo (básicamente, dependiendo de los problemas que tenga la sociedad en la que se circunscribe $)^{6}$, es posible encontrar marcas propias que permitan delimitar los contornos del populismo desde un punto de vista discursivo, la macroestructura del discurso populista :

El discurso populista nace en una situación de crisis social. Consiste, por lo tanto, en describir esta situación cuya víctima es el pueblo, en denunciar la fuente del mal, y en alabar los méritos de un líder particularmente carismático. Este líder no tiene un programa político propiamente dicho, sino que promete romper con las prácticas del pasado, terminar con la corrupción y devolver su poder al pueblo. También se constata que, desde el punto de vista ideológico, el populismo no tiene homogeneidad (Le Pen/Chávez). Esta constatación de no homogeneidad ideológica debería incitarnos a ser prudentes en cuanto a la manera de categorizar el populismo. En definitiva, se impone presentar (1) una descripción catastrófica de la situación social de la que es víctima el pueblo; (2) una denuncia de los culpables, entre los cuales se encuentran la clase política, las élites aisladas del pueblo, las instituciones que han perdido toda autoridad y la burocracia, fuente de todos los males; (3) la exaltación de valores y (4) la aparición de un hombre/mujer

${ }^{5}$ En definitiva, el discurso populista es un discurso esencialmente político desde la perspectiva de que es maniqueo, simplificador y se dirige a las emociones primarias. Desde este punto de vista coincide con el lenguaje político en general. El estudio que hace P. Charaudeau («La argumentación persuasiva. El ejemplo del discurso político», en Shiro M. \& alii, Haciendo discurso. Homenaje a Adriana Bolivar, Facultad de Humanidades y Educación, Universidad Central de Venezuela, Caracas, 2009, págs. 284-289) de la argumentación persuasiva en el lenguaje político pone de manifiesto el paralelismo evidente del discurso populista y el discurso político.

${ }^{6}$ P. Charaudeau (loc. cit., pág. 258): Estas diferentes figuras del populismo (Le Pen, Sarkozy, Collor de Mello, Fujimori...) muestran que no se puede delimitar una definición única de esta noción, ya que los contextos históricos y políticos la modifican de manera variable. Habría populismos «clasistas», incluso «etnicistas» (racistas); populismos «nacionalistas», más o menos autoritarios, que juegan con la identidad nacional y la segregación; populismos «neoliberales», coyunturales, que se manifiestan en las campañas electorales por medio de expresiones demagógicas, con el fin de seducir a las masas populares.

Se define el discurso populista por coincidencia formal; Chávez y Le Pen hacen discurso populista, independientemente de su ideología.

7 Textos tomados de P. Charaudeau, «Reflexiones para el análisis del discurso populista» y «Las emociones como efectos de discurso», Revista Versión, no. 26, junio 2011, págs. 97-118. 
providencial, carismático, visionario, capaz de romper con el pasado y que será el salvador de la sociedad.

El discurso populista presenta, pues, este orden narrativo basado en esos cuatro puntos sobre el que gravitan los argumentos mencionados. Tales argumentos vienen acompañados de un tipo de lenguaje propio. P. Charaudeau ${ }^{8}$ recoge también alguna de sus características:

El líder populista debe ser un «maestro de la palabra» por el manejo de un lenguaje y de una retórica que forman parte de la dramaturgia política. Una vez más, lleva al exceso las características del discurso político. Su lenguaje debe ser particularmente sencillo y comprensible, tanto más cuanto pretende erigirse contra el lenguaje estereotipado [...] se trata de conmover las conciencias mediante el empleo de fórmulas, a veces metafóricas, destinadas a esencializar el mal que padece el pueblo, la figura de los culpables o la esperanza de días mejores: el mal será designado por palabras que remiten al miedo, a la decadencia, a la desesperación, los culpables serán demonizados, la esperanza será como un camino de luz. Desde el punto de vista de lo que se denomina el registro de lengua, el populista utiliza a menudo un vocabulario familiar, a veces vulgar, incluso escatológico o insultante respecto de los adversarios, a veces aguerrido, que se permite, como se ha visto, exabruptos, juegos de palabras, reflexiones irónicas que actúan como flechas envenenadas. Su argumentación simplifica las relaciones de causa a efecto («Un millón de inmigrantes, un millón de desempleados» profería Jean-Marie Le Pen en los años noventa); practica la amalgama en la descripción de los actos de agresión mezclando actos menores y actos mayores (gran bandolerismo, pequeña delincuencia, ratería, destrozos, violaciones colectivas, golpizas, etc.); o la amalgama de las causas (por ejemplo, poner en la misma bolsa causas de la inseguridad: el desempleo, el uso de droga, la ineficacia policial, el laxismo de la Justicia, la indiferencia de las élites políticas). Y para respaldar sus palabras, recurre a cifras y porcentajes proferidos a bocajarro sin posibilidad de verificación: «El aumento en potencia de estos fenómenos, consecuencia de la inmigración, sigue la misma curva, todos los años: el desempleo, la criminalidad, la delincuencia, la droga aumentan entre un $8 \%$ y un $10 \% »$. En cuanto al posicionamiento del orador populista, éste se expresa en un juego de pronombres entre un «Nosotros», que abarca al orador, a su partido, a sus partidarios, al pueblo; un «Yo» que se afirma, repetimos, como potente, voluntario, que se asume y se compromete totalmente («yo quiero», «yo digo», «yo afirmo»); e incluso un «Él» de teatralización, autodesignándose como el protagonista de una búsqueda de Salvación. Todo esto tiene lugar en una escenificación a su vez fuertemente teatralizada (inmensos podios, lugares y decorados simbólicos, multitud compacta), y, si es posible, con una producción corporal, vocal y gestual de barricada por parte del orador.

${ }^{8}$ Loc. cit., págs. 270-272. 
El estudio de Charaudeau ya contempla un populismo corrompido. El discurso populista no es sincero, es interesado, es excesivo y de él nace el uso y abuso de populismo/populista como un término de degradación política dentro del juego de estereotipos que en España se populariza con la llegada de Podemos al panorama político español.

Partiendo de la plantilla que propone Charaudeau, hay que reconocer que es Podemos quien acumula más características del tipo de discurso que se define como populista ${ }^{9}$. Pablo Iglesias puede considerarse un líder populista, su lenguaje lo es en gran parte y sus argumentos podrían calificarse así, ya que el pueblo es el protagonista absoluto y las propuestas, en muchos casos, se reconocen como difíciles de llevar a cabo. Recordemos lo que apuntaban José Ignacio Conde-Ruiz / Juan Rubio-Ramírez (15-07-2014) en El País ${ }^{10}$ :

El programa [de Podemos] es una maravilla desde el punto de vista de las relaciones públicas y el marketing, pero rezuma populismo por todos los costados. Las 36 páginas proponen, entre otras medidas, el impago de parte de nuestra deuda soberana, la pérdida de independencia del Banco Central Europeo, la democratización y nacionalización del sistema bancario, una renta básica para todos los ciudadanos, la moratoria de algunas deudas hipotecarias, el abandono de algunos de nuestros tratados de libre comercio o bajar la edad de jubilación a los 60 años. A primera vista, todas estas medidas suenan de maravilla y son muy atrayentes para la gran masa de descontentos a la sombra de la crisis que parece no querer abandonarnos. Pero analizadas con un poco de sentido común no pasan la prueba del algodón. No pagar la deuda soberana tendría consecuencias inimaginables sobre nuestra capacidad, como país, de acceder a los necesarios mercados financieros; la democratización del Banco Central Europeo traería consigo la ya casi olvidada inflación; la nacionalización del sistema bancario niega que fueron las instituciones financieras controladas por el sector público las más afectadas por la crisis; la renta básica parece milagrosa pero el programa electoral obvia el problema de su financiación; la moratoria hipotecaria generalizada haría un daño irreparable al futuro de nuestro sistema hipotecario; abandonar los tratados de libre comercio sería sinónimo de pobreza en muchos de los países que los firman y bajar la edad de jubilación niega las dinámicas demográficas a las que nos enfrentamos.

${ }_{9}^{9}$ Por ejemplo, responde a huir de etiquetas que lo relacionen con la derecha o la izquierda: De nuevo, a pesar de las preguntas, el representante de Podemos se ha negado a situar a la formación en la izquierda o la derecha políticas. Ambos términos, como el de centro, ha dicho, son solo «metáforas» (Í. Errejón, El País, 13-11-2014).

«La mayor parte de la gente no se ve representada hoy ni en los dos partidos políticos dominantes, ni en la vieja izquierda», responde. «Izquierda y derecha son metáforas, son nombres nada más, y no son eternos. Nosotros representamos el sentido común contenido en una identidad transversal y popular, frente a la oligarquía» (Í. Errejón, El País, 27-01-2015).

${ }^{10}$ Algunos meses después, cuando Podemos aparece en las encuestas como primer partido en cuanto a intención de voto, algunas de estas propuestas empiezan a «matizarse»: empieza la adaptación del discurso a las nuevas circunstancias políticas. 
Efectivamente, Podemos surge en un momento de crisis, de hartazgo de los ciudadanos y de corrupción; hay una fuente del mal (los políticos [la «casta» como los denomina el grupo] y los banqueros) y hay un líder. El resto de los partidos no surgen en el momento de la crisis, ni cambian radicalmente su discurso aunque sí empleen puntualmente argumentos populistas; no señalan una fuente del mal y no presentan un líder carismático prototípico. Desde este punto de vista, Podemos responde con precisión a la macroestructura del discurso populista de la que hablaba Charaudeau, si bien, en el detalle, se aleja un poco del populismo canónico. En el discurso de Podemos, por ejemplo, sí existe un programa económico, aunque no un claro programa político ${ }^{11}$, no se reconocen «complots», no hay una adhesión ciega al líder; a pesar de que se emplea un vocabulario familiar, no es vulgar, ni escatológico, aunque sí insultante (denominar «casta» o «mangantes», «pistoleros», «golfos», «sinvergüenzas» 12 a los políticos adversarios lo es), etc. El discurso de Podemos no se plantea tan excesivo como los discursos de Chávez o Le Pen, aunque, como en el caso de los citados líderes políticos, sí se erige como protagonista de un cambio, de un nuevo ciclo, de un nuevo régimen:

Queremos que sea una movilización histórica. Queremos que la gente pueda decir a sus nietos que estuvo en la marcha que abrió el cambio de ciclo en España (El País, 12-01-2015).

La intervención de Pablo Iglesias como candidato a la presidencia del Parlamento Europeo ${ }^{13}$ es una prueba palpable de este modelo de discurso político.

Parte de la presentación de una Europa construida por el pueblo a base de luchar por la libertad y la democracia frente la intolerancia la xenofobia y el fascismo (párrafos 1, 2 y 3) para mostrar, frente a ella, la Europa de hoy, infectada por una oligarquía financiera y una clase política solo atenta a sus propios beneficios y que hurtan todos los logros conseguidos por el pueblo hasta «secuestrar su soberanía» (párrafos 4, 5 y 6). Son los antagonistas de este relato.

En el párrafo 7 se produce el punto de inflexión que marca la «hora crítica para Europa». Ante este un panorama sombrío, caótico, desesperado, de una

${ }^{11}$ El 23 de abril de 2015 todavía no había dado a conocer su programa político:

Este retraso ha convertido a Podemos en el único partido entre los que tienen aspiración de ganar que todavía no ha concretado las líneas maestras de su proyecto. Falta un mes para las autonómicas, las elecciones más importantes antes de las generales del próximo otoño, y quedan dos semanas para el arranque de la campaña electoral (El País, 23-04-2015).

12 https://www.youtube.com/watch?v=Yizw-RySZnI (20-11-2014). También hay que tener en cuenta que el insulto es habitual en el lenguaje político. Desde este punto de vista, Podemos no se diferencia mucho de otros. El propio Toni Canto (UPyD) denominaba a los miembros de Podemos «castuza» (Europa Press, 25-01-2015), y no hace falta recordar la calificación de «bobo solemne» de Mariano Rajoy al entonces presidente José Luis Rodríguez Zapatero (El Mundo, 19-02-2005). Por tanto, lo que realmente hace que un discurso sea populista es la suma de características.

13 Véase Anexo. 
Europa sin esperanza dominada por las «elites» políticas y financieras, entra el Yo. El líder (párrafos 8-9) que se dirige a los ciudadanos, no a los partidos, no a los parlamentarios, en un mensaje personal y emotivo que pretende hacer reflexionar a los individuos para ayudar a los países a «ponerse en pie».

En el párrafo 10 habla a su pueblo como un líder autorizado para elogiarlo y animarlo a seguir en la lucha con una promesa de victoria.

Si aplicamos la plantilla de Charaudeau a este discurso, cuadra:

(1) Una descripción catastrófica de la situación social de la que es víctima el pueblo; párrafos del 1 al 6, incluso parte de los siguientes.

(2) Una denuncia de los culpables, entre los cuales se encuentran la clase política, las élites aisladas del pueblo, las instituciones que han perdido toda autoridad y la burocracia como fuente de todos los males; sobre todo, párrafos 4,5 y 6 .

(3) La exaltación de valores; párrafos 1, 8 y 9

(4) La aparición de un hombre/mujer providencial, carismático, visionario, capaz de romper con el pasado y que será el salvador de la sociedad; párrafo $10^{14}$.

En cuanto a la estructura, populismo en estado puro.

En definitiva, la macroestructura de la que habla Charaudeau y que reproduce Pablo Iglesias en su discurso se apoya en la estructura de un relato, se sostiene sobre la base de la narratividad como estrategia discursiva para la persuasión del destinatario, una selección argumentativa que crea un relato: los pueblos europeos ${ }^{15}$ ven amenazada ${ }^{16}$ su democracia y su libertad por oligarquías financieras y representantes políticos convertidos en casta. El pueblo debe luchar para conseguir la victoria guiados por el líder en una batalla de la que saldrá vencedor. Este es el relato al que acompaña una selección léxica perfectamente intencionada que persigue estimular sentimientos, emociones, conmocionar al destinatario con el fin de que apoye la causa y pasar de la conmoción a la acción. Selección léxica y narratividad ${ }^{17}$ vuelven a conformar los

${ }^{14}$ Los propios miembros de Podemos emplean la terminología al uso:

Pablo Echenique quiso dejar claras que las diferencias con Iglesias solamente se encuentran en el modelo organizativo, ya que ellos apuestan por el «macho alfa» para liderar Podemos, porque «necesitamos un líder carismático y ya tenemos al mejor» (La Razón, 19-10-2014).

15 Palabra principal del discurso: 14 apariciones en dos folios.

16 Amenazar y sus variables aparecen en 7 ocasiones en este breve discurso.

17 J. Bruner («Narrative Construction of Narrative», University of Chicago, Critical Inquiry, 18, 1991, pág. 4) considera que el sujeto accede al conocimiento del mundo a través de estructuras narrativas. El ser humano es, en esencia, un ser narrativo. «El relato se considera el medio apropiado por el cual los hechos del mundo se vuelven inteligibles para las personas» (E. Montolío, Acción política y comunicación. Elaboración y análisis de un corpus de narraciones de experiencias comunicativas relatadas por dirigentes políticas del ámbito hispanohablante, Centro Eurolatinoamericano de Formación Política Mujeres y Ciudad. <http.//urbal.diba.cat/mujeresyciudad/archivos/ novedades_archivos/Discurso_comunicacion_accion_Estrella_Montolio.pdf.>24/11/2011), ya que las personas, inevitablemente, seleccionan, organizan y disponen sus vivencias de un modo narrativo. La construcción de la realidad a través de la narración es, por tanto, el recurso cognitivo básico por el cual los seres humanos conocen el mundo y, además, a ellos mismos. No es raro si pensamos que, desde que nacemos, el cuento está integrado en nuestras vidas, un 
pilares básicos de este discurso político ${ }^{18}$. Necesitamos estimular un marco cognitivo ${ }^{19}$ concreto y seleccionamos un léxico determinado que podemos insertar en el argumento de una historia previamente seleccionada. Así funciona, en muchas ocasiones, la comunicación persuasiva.

Así pues, selección léxica y relato forman un tándem letal en lo que a la persuasión se refiere y, en el caso que nos ocupa, constituye el armamento fundamental de la persuasión. Así se puede observar en el discurso de Pablo Iglesias a la presidencia del Parlamento Europeo.

Del mismo modo, el lenguaje populista es lenguaje político, y como lenguaje político, presenta un mundo maniqueo, un mundo simplificado en el que solo aparecen buenos y malos, un mundo sin matices en el que se crea un estereotipo positivo propio y uno negativo del contrario ${ }^{20}$.

cuento con una estructura concreta, con una morfología muchísimas veces idéntica, como ya hemos tenido oportunidad de ver. Esta familiaridad con el formato provoca una asimilación rapidísima de los contenidos.

${ }^{18}$ P. Charaudeau (op. cit., pág. 290) aplica el mismo esquema al discurso político general, si bien, como mostraremos más adelante, desde nuestro punto de vista, hay grados: Los sentimientos de afecto circulan entonces en este universo y, como están en relación directa con la dimensión emocional de los individuos, aparecen en una puesta en escena dramatizada de acuerdo con un guion susceptible de influir en el público de forma positiva o negativa. El discurso político, aun cuando no es el único, realiza esta puesta en escena siguiendo el guion clásico de los cuentos populares y de los relatos de aventura: una situación inicial en la que se describe un mal, la determinación de la causa de ese mal y la reparación de ese mal por medio de la intervención de un héroe natural o sobrenatural. El discurso político, que busca que el público se adhiera a un proyecto o a una acción, o que busca disuadir a ese mismo público de seguir un proyecto adverso, enfatiza más particularmente el desorden social del cual es víctima el ciudadano, señalando la fuente del mal encarnada en un adversario, y la solución salvadora encarnada en el político que hace el discurso.

${ }_{19}$ A. G. Greenwald («Cognitive learning, cognitive response to persuasion, and attitude change», en A. G. Greenwald, T. C. Brock and T. M. Ostrom, eds., Psychological foundations of attitudes, Academic Press, Nueva York, 1968, págs. 147-170) formuló su teoría de la respuesta cognitiva, según la cual las personas comparamos la nueva información que recibimos con otras informaciones existentes que recordamos, además de con los sentimientos que hemos ligado a esos recuerdos y con nuestras experiencias biográficas, y a partir de ahí, interpretamos. Puede consultarse Van Dijk (Discurso y contexto, Gedisa, Barcelona, 2012) para un repaso y una explicación exhaustiva sobre la teoría de los modelos mentales. En la misma línea, la Teoría de los Marcos Cognitivos (G. Lakoff, No pienses en un elefante, Editorial Complutense, Madrid, 2007) o la Teoría de la Relevancia (D. Sperber y D. Wilson, La relevancia. Comunicación y procesos cognitivos, Visor, Madrid, 1994 [1986]).

${ }^{20}$ John Carlin en El País (29-01-2015) lo describe con claridad: «No hay ideologías, no hay programas, no hay ni siquiera, como declaró Pablo Iglesias en Vall d'Hebron, promesas. ¿Entonces qué hay? Hay una narrativa. Hay una historia digerible, un mensaje breve - tuiteable-y un llamamiento a las emociones [...]».

Hablando de Dios, el mensaje de Podemos contiene permanentes alusiones cristianas. Lo que venden, en el fondo, es el mensaje de Cristo, el de aquel Cristo indignado que cuando llegó al templo denunció a los mercaderes y, en las palabras del evangelio, «echó fuera a todos los que compraban y vendían en el templo, y volcó las mesas de los cambistas... Y les dijo: 
Tal y como señala B. Gallardo²1, una de las tres funciones estratégicas de la política es la de legitimación/deslegitimación ${ }^{22}$ :

Legitimación/deslegitimación: la creación de la imagen propia favorable («las técnicas utilizadas incluyen argumentos sobre los deseos de los votantes, sobre principios ideológicos generales o la proyección de liderazgo carismático, haciendo alarde del desempeño y la auto-presentación» [Chilton y Scháffner 1997: 213]), y de la imagen desfavorable del oponente («las técnicas incluyen el uso de ideas sobre diferencias y límites, y los actos de habla de culpar, acusar, insultar, etc.» [Chilton y Scháffner 1997: 213]).

$$
[\ldots]
$$

Esta oposición enunciativa determina lo que Van Dijk llama la «escuadra ideológica» $(1998,2005,2006)$, de la que nos ocuparemos al abordar los roles participativos del texto político, a saber: «la habitual escuadra ideológica de polarización discursiva de grupo (atenuar/enfatizar las cosas buenas/malas suyas/nuestras)» (2006: 374$)$.

Tal oposición pudo verse con mucha claridad en el debate entre Rubalcaba y Rajoy para las elecciones de noviembre de 2011. Así lo recogían los medios de comunicación:

Las conclusiones otorgan, en cualquier caso, el triunfo del debate electoral al líder del PP, ya que la estructura de su discurso estuvo mejor construida que la de Alfredo Pérez Rubalcaba. Mariano Rajoy utilizó en mayor medida, pero de forma equilibrada, los datos y su exposición se decantó por el planteamiento de un mayor número de escenarios negativos que positivos (M. Fabra, El País, 8-11-2011).

O Gallardo (op. cit., pág. 188) en su estudio sobre los argumentarios de PP y PSOE:

En el discurso expresivo de valoración, ambos partidos coinciden en dar más peso a los actos de ataque al oponente (62\% el PP, $69 \%$ el PSOE) que a los de autoelogio ( $38 \%$ el PP, $31 \%$ el PSOE).

\footnotetext{
"Escrito está: mi casa será llamada casa de oración pero vosotros la estáis haciendo cueva de ladrones"» [...].

En la era posideológica y posreligiosa en la que vivimos, los ecos de aquellos textos aún resuenan en las mentes de los habitantes de un país de larga tradición católica como España. En los evangelios, a los malvados los llamaban fariseos, en la narrativa de Podemos los llaman casta. Es un mensaje que apela más a los sentimientos que al raciocinio, a nociones atávicas de la lucha del bien contra el mal.

${ }^{21}$ B. Gallardo, Usos políticos del lenguaje, Anthropos, Madrid, 2014.

22 Las otras dos son (B. Gallardo, loc. cit., pág. 91) la Coacción como «discurso orientado a condicionarla conducta de los demás [...] y el «encubrimiento: corresponde al control del flujo informativo [...]. El encubrimiento incluye diversas técnicas, que van desde el uso del eufemismo o la falacia circular y la anfibología a la mentira evidente».
} 
Así pues, desde el punto de vista léxico y argumentativo, siguiendo las pautas generales del discurso político, la exposición de Pablo Iglesias presenta un desequilibrio patente entre la descripción de un panorama desolador, una situación política que amenaza todos los derechos del pueblo, presentada con una selección léxica de negatividad absoluta, frente a la alternativa que se ofrece para neutralizar esa situación que asfixia la democracia. Solo la suma de términos e ideas sería suficiente para completar la narración que plantea:

\begin{tabular}{|l|l|}
\hline Intolerancia & Millonarios a sueldo de grandes empresas \\
Xenofobia & Hurta la soberanía de los pueblos \\
Miedo a la pobreza & Destruyendo derechos sociales \\
Exclusión & Amenazando la cohesión social \\
Desempleo & Mando y saqueo de los pueblos del sur \\
Siervos & Racismo \\
Pobreza & Destruir el proyecto europeo \\
Exclusión & Miseria pobreza y violencia \\
Desempleo & Políticas de empobrecimiento \\
Desamparo frente a la enfermedad & Secuestro de la soberanía \\
Expropiación de la soberanía & Deriva autoritaria de la troika \\
Sometimiento del gobierno & Países más pobres \\
Amenazan nuestra dignidad & Economías destruidas \\
Amenazan la igualdad, la libertad y la fra- & Sociedades heridas de injusticias \\
ternidad & Instituciones cuarteadas por la corrupción \\
Amenazan nuestra vida en común & y el descrédito \\
Pagar el precio de incapacitar a la ciudadanía & Secuestro de la democracia \\
Colonias de ningún fondo de inversión & Austeridad y totalitarismo financiero \\
Oligarquía financiera & Déspotas \\
Lobbies al servicio de grandes corporaciones & \\
\hline
\end{tabular}

Frente a este aluvión de negatividad y desastre democrático, el líder opone un mensaje puramente emocional, se dirige al corazón de los eurodiputados para «demostrar sensibilidad y convertirse en el epicentro de una sacudida democrática en la Unión Europea», para «expresar la legitimidad democrática de origen que a todos nos reúne, la voz de los ciudadanos» porque «ustedes tienen un contrato de responsabilidad política firmado con sus pueblos»; «Ustedes saben que es hora de ayudar a nuestros países a ponerse de nuevo en pie. Les pido que al menos hoy voten como griegos, como irlandeses, como portu-gueses, como italianos, como checos, como polacos, como rumanos, como españoles. No sólo para que puedan mirar a la cara a su gente cuando vuelvan a casa», «sabiendo que muchos de ustedes están sinceramente comprometidos con el bienestar de sus pueblos». Apela, por tanto, a su sensibilidad y responsabilidad para luchar contra el «secuestro de la democracia» aunque pesa más la presentación negativa del adversario que las propias armas para luchar contra ello. 
Y concluye dirigiéndose al pueblo, alentando al pueblo a seguir en la lucha:

Quiero dirigir mis últimas palabras a la ciudadanía y a los pueblos de Europa que han salido a la calle en estos años para defender justicia social y la democracia. A los millones que habéis dicho basta en las plazas europeas, quiero deciros que sois el orgullo, el corazón democrático de Europa. Mantened alta la bandera de la dignidad. Los pueblos de Europa hemos pasado por peores situaciones y nos hemos sacudido a los déspotas. No sé si hoy podremos arrebatarle la presidencia de este parlamento a la gran coalición pero si nos seguís empujando os aseguro que venceremos. El mañana es nuestro (P. Iglesias, Discurso para la Presidencia del Parlamento Europeo, 30-06-2014).

Comienza su conclusio con la primera persona del singular y termina con la primera del plural en un Yo/Nosotros que calca la descripción que del discurso populista hace Charaudeau.

En cierto modo, sigue la macroestructura que reconoce F. Moreno Fernández ${ }^{23}$ en los manifiestos del movimiento indignado. El discurso de Pablo Iglesias a la Presidencia del Parlamento Europeo gravita, al igual que las obras de Stéphane Hessel o José Luis Sampedro, entre «los elementos que provocan la indignación y que conforman un panorama de negatividad y pesimismo» y el segundo hilo que dibuja un panorama de esperanza, enlazando elementos que la evocan y que la hacen necesaria, así, «la estrategia discursiva consistente en una descripción de calamidades, generadora de una indignación que ha de mitigarse con el entusiasmo de la esperanza» (F. Moreno Fernández, op. cit., pág. 20). Al fin y al cabo, la política clona el relato de la vida.

Los manifiestos de Democracia Real Ya, Yo soy \#15M o los carteles que llenaron las plazas donde acampaban los seguidores del movimiento son un elemento más de encuentro entre la estructura de ambos discursos:

[...] es interesante identificar, como en los textos de Hessel o Sampedro, dos paradigmas perfectamente diferenciados y enfrentados: el de la indignación y el de la esperanza. El primero vertebra la relación de causas que llevan a la indignación y está constituido por expresiones sustantivas como listas cerradas, minorías poderosas, situaciones desesperadas, especulación financiera, crisis histórica, violencia. El segundo paradigma permite elaborar una enumeración de reclamaciones y fijar unos objetivos cuyo cumplimiento se espera: diversidad ideológica, democracia mejor, participación ciudadana, responsabilidad política, libertad de expresión. La carga positiva de estas expresiones se refuerza cuando, en algunos casos, se oponen en las mismas frases a sus antónimas: corrupción de candidatos / controles ciudadanos; privilegios

${ }^{23}$ F. Moreno Fernández, Spanish Revolution: ensayo sobre los lenguajes indignados, Uno y Cero Ediciones, Valencia, 2014. 
fiscales / control fiscal; manipulación mediática / libertad de expresión (F. Moreno Fernández, op. cit., pág. 26) ${ }^{24}$.

Ahora bien, el repaso de los textos impresos o pintados en los centenares de carteles, pósteres y pancartas que hemos podido analizar con detenimiento nos descubre que el discurso lematizado entre todos ellos también refleja una vertebración en dos paradigmas generales, como en los 59 textos fundacionales y en los manifiestos: el de la indignación y el de la esperanza. Así, a la dictadura y la timocracia se le opone la democracia; al valor añadido, los valores universales; a la corrupción, la justicia; a la resignación, la resistencia; a la estafa y el fraude, la dignidad; al privilegio, la unidad; al robo, el bienestar; a la violencia, la paz; a la indignación, la felicidad; y así hasta completar una larga relación (F. Moreno Fernández, op. cit., págs. 59-60).

Lo cierto es que en el discurso político este maniqueísmo es muchas veces artificial, se busca la eficacia en el ataque político, es, como decía Barthes, retórica negra ${ }^{25}$, mientras que en el discurso de los indignados la negatividad coincide con el pensamiento de gran parte de los ciudadanos, no parece una impostura.

${ }^{24} \mathrm{Si}$ bien hay coincidencias, igualmente, en la causa de aparición del movimiento indignado y los movimientos populistas, ...el movimiento social que expresa la indignación ciudadana por un orden económico calificado de injusto, un sistema de partidos que no se considera representativo y una organización social acusada de mermar las libertades individuales y penalizar a los desprotegidos (F. Moreno Fernández, loc. cit., pág. 8).

Algunos de los carteles más representativos del movimiento van en la misma línea:

Sin el pueblo no sois nada

La banca al banquillo

¿Por qué mandan los mercados si yo no los he votado? No a la dictadura financiera

No hay pan pa tanto chorizo

Pienso, luego RESISTO

No somos mercancía en manos de políticos y banqueros

Que no nos representan

También existen claras diferencias como es, sin duda, la falta de liderazgo en el movimiento indignado frente al líder carismático populista.

25 «En efecto, si nos fijamos, por ejemplo, en el campo de la oratoria política, es claro que estamos asistiendo hoy a un auge importante de (lo que Roland Barthes) llama «retórica negra», es decir, a un uso de la Retórica que tiende a la manipulación, pues, escamoteando el elemento problemático y polémico, y ocultando o sencillamente descalificando sin más los posibles argumentos contrarios, o, incluso, utilizando deliberadamente argumentos falaces, pretende, de una manera simplista, presentar todo como si fuera muy claro, y convertir en justo, verídico y congruente lo que en realidad no lo es [...]. La mayor parte de las veces, de lo que se trata es de conseguir la adhesión y el apoyo a decisiones previa y unilateralmente tomadas, recurriendo a una lógica perversa, la que Meyer denomina «lógica del depredador», que se basa en alternativas simples, o mejor, simplistas (blanco o negro, el bien o el mal, «o estás conmigo o estás contra mí», «o con Bush o con Sadam»), y que escamotea deliberada e interesadamente el hecho de que la realidad es mucho más compleja que como se la presenta» (S. Crespo Matellán, «La retórica en la era de la globalización», Logo. Revista de retórica y teoría de la comunicación, 6, 2004, págs. 60-70). 
Por otra parte, y siguiendo con un trabajo de selección léxica perfectamente estudiado ${ }^{26}$, en poco más de dos folios, vuelven a la arena política términos y expresiones propias de otros momentos de la historia de España o de otros momentos de la historia del discurso político. Tal es el caso del uso de siervos, que llama inmediatamente a la oposición criados/siervos, amos/siervos, con las implicaciones cognitivas que posee este tipo de vocabulario. El marco cognitivo que se recupera con su uso vuelve los ojos a desigualdades sociales propias de épocas de injusticia social extrema y de lucha de clases.

El mejor patrimonio de Europa es la voluntad de sus ciudadanos de ser libres y no ser siervos de nadie. No ser siervos de nadie, señorías, eso es la democracia.

No hay más que observar el índice del denominado Podemos. Documento Final del Programa Colaborativo que se recoge en la página web del grupo político (http://podemos.info) para darse cuenta de la recuperación de este lenguaje:

ÍNDICE

1. Recuperar la economía, construir la democracia

2. Conquistar la libertad, construir la democracia

3. Conquistar la igualdad, construir la democracia

4. Recuperar la fraternidad, construir la democracia

5. Conquistar la soberanía, construir la democracia

6. Recuperar la tierra, construir la democracia

Conquistar, tierra, igualdad, fraternidad...

Otros términos empleados en el discurso para la Presidencia al Parlamento Europeo sugieren, igualmente, una retórica de lucha enraizada en las revoluciones de principios del siglo pasado y que fueron decayendo con el paso de los años, o en las revoluciones que se produjeron en Latinoamérica en los años 70 y que fueron, en muchas ocasiones, fuente inspiradora en los años de la Transición española a la democracia. Términos como oligarquía, empleados con profusión incluso en la Transición por los partidos de izquierda ${ }^{27}$ en la actualidad han disminuido enormemente su frecuencia, que solo empieza a recuperarse hoy porque, de nuevo, cambian las circunstancias o porque se recupera un tipo de lenguaje que pretende distanciarse y distinguirse del modelo actual.

${ }^{26}$ No hay que perder de vista que Podemos posee una infraestructura de asesoría política que analiza cada paso del líder. Fueron públicos los documentos Salvados: cara a cara Iglesias vs Rivera y Estrategia de comunicación del secretario general, en abril del 2015, publicados, entre otros, por El confidencial. En ellos se dan instrucciones muy precisas sobre lenguaje, actitudes, conductas, argumentos, gestos y demás cuestiones de asesoría política.

27 J. de Santiago Guervós. El léxico politico de la transición española, Universidad de Salamanca, 1992 
Como señala Huici Módenes²8,

[...] cuando una revolución triunfa, una de las primeras cosas que hacen los líderes revolucionarios es intervenir sobre el lenguaje, modificar el léxico como una forma de reforzar la idea de que la realidad ha cambiado, que es distinta [...] naturalmente, quien controla las palabras e impone los significados está en condiciones de establecer una nueva realidad.

El lenguaje oculta los hechos o los revela, y, así, como en las obras de George Orwell, el discurso de Podemos va cambiando la neolengua que se ha ido introduciendo desde la Transición hasta el momento actual para recuperar una lengua vetusta que hace cambiar la ciudadanía por el pueblo o gente ${ }^{29}$, la economía de mercado por el capitalismo, las personas con rentas elevadas por los ricos. Toda esa neolengua eufemística que trasforma o desdibuja la realidad vuelve a sus orígenes espoleada por un discurso que plaga sus frases con términos que buscan una respuesta emocional. Naturalmente, quien controla las palabras e impone los significados está en condiciones de establecer una nueva realidad, $s u$ realidad ${ }^{30}$.

Fascismo y antifascismo, totalitarismo, oligarquía, el trinomio igualdad, libertad y fraternidad, la mención constante del pueblo, venceremos o «el mañana es nuestro» recuerdan un discurso clásico, antiguo, que actualiza el líder de Podemos, o un discurso heredado de las luchas contra las dictaduras latinoamericanas donde este vocabulario era moneda común. No hay más que recordar las letras de canciones que se convirtieron en himnos en los años 70 en aquellos países y que fueron recibidas en España con el mismo valor liberador. El conocimiento autobiográfico de muchos de esos términos estimula un marco cognitivo de descodificación en el que muchos eran jóvenes y vivían ansias de libertad que hoy pueden recordarse con nostalgia; actualiza emociones. Las letras de algunas de esas canciones, recuerdan a la retórica que emplea Pablo Iglesias en sus discursos:

\section{Venceremos}

Desde el hondo crisol de la patria se levanta el clamor popular, ya se anuncia la nueva alborada, todo Chile comienza a cantar. Recordando al soldado valiente cuyo ejemplo lo hiciera inmortal, enfrentemos primero a la muerte, traicionar a la patria jamás.

28 A. Huici Módenes, Guerra y propaganda en el siglo XXI, Alfar, Sevilla, 2010, pág. 101.

${ }^{29} \mathrm{La}$ evidencia de la efectividad del nuevo lenguaje de Podemos provoca la reacción inmediata de los adversarios políticos. Podemos habla constantemente de gente, gente es a Podemos como ciudadanos a la revolución francesa, y el PP asume inmediatamente el nuevo lenguaje que parece que se impone: PP es el partido de la gente. Somos gente y la gente habla en las plazas (C. Floriano, PP, elplural.com, 2015-01-23).

${ }^{30}$ A. Huici Módenes, op. cit., pág. 116. 
Venceremos, venceremos, mil cadenas habrá que romper, venceremos, venceremos la miseria (al fascismo) sabremos vencer.

Campesinos, soldados, mineros, la mujer de la patria también, estudiantes, empleados y obreros, cumpliremos con nuestro deber. Sembraremos las tierras de gloria, socialista será el porvenir, todos juntos haremos la historia a cumplir, a cumplir, a cumplir (Quilapayún, 1971).

\section{El pueblo unido jamás será vencido}

El pueblo unido, jamás será vencido, el pueblo unido jamás será vencido... De pie, cantar que vamos a triunfar. Avanzan ya banderas de unidad. Y tú vendrás marchando junto a mí y así verás tu canto y tu bandera florecer. La luz de un rojo amanecer anuncia ya la vida que vendrá.

De pie, luchar el pueblo va a triunfar. Será mejor la vida que vendrá a conquistar nuestra felicidad y en un clamor mil voces de combate se alzarán, dirán canción de libertad, con decisión la patria vencerá.

Y ahora el pueblo que se alza en la lucha con voz de gigante gritando: ¡adelante!

El pueblo unido, jamás será vencido, el pueblo unido jamás será vencido...

La patria está forjando la unidad... (Quilapayún, 1975).

De hecho, la canción protesta de la transición se entroniza en el discurso de Podemos. Canciones de la Guerra Civil española («En el puente de los franceses»), Mercedes Sosa, Luis Llach o Quilapayún suenan en sus mítines y son entonadas por sus dirigentes con el puño en alto.

Al lado de la recuperación de estos términos del vocabulario de la izquierda en la II República y de la Transición (por no irnos más lejos en la historia política española), emplea otros que durante los últimos años estaban proscritos en este tipo de discurso en España, pero que, como hemos visto, no lo estaba en la luchas contra las dictaduras de los años 70 en la América latina ${ }^{31}$.

Millares de compatriotas míos, que habían luchado defendiendo la democracia en España, participaron en esa lucha y en ese sueño de justicia. No se imaginan el orgullo que me produce como español que los primeros tanques que entraron a liberar Paris fueran guiados por combatientes españoles (P. Iglesias, Discurso para la Presidencia del Parlamento Europeo, 30-06-2014).

El secretario general de Podemos, Pablo Iglesias, ha afirmado este lunes que si como gobernante le pusieran «entre la espada y la pared» para obligarle a hacer recortes y que «los tenedores de la deuda cobren sus intereses» él optaría por tomar «medidas patrióticas» (Europa Press, 17 de noviembre de 2014, 11:05).

${ }^{31}$ En una entrevista en el programa de televisión de La Sexta, Salvados (26-10-2014), afirmaba, a propósito del sacrificio económico que podía suponer crear un tope salarial o subir los impuestos a las grandes fortunas, que «Hay que pedir un poco de patriotismo a la gente» para trabajar en beneficio de la comunidad. 
Sorprendente patriotismo y españolismo de izquierda, inaudito desde tiempos anteriores a la II República. Parece que el líder de Podemos se nutre más de la retórica de los partidos de izquierda de procedencia latinoamericana que de la izquierda española, ya que en la etapa republicana, España y patria ${ }^{32}$ ya empezaban a ser identificados con la derecha y extrema derecha hasta llegar al uso y abuso que se hizo de ellas en la dictadura franquista y en la Transición a la democracia en España después de la muerte del dictador ${ }^{33}$.

¿Es una estrategia para atraer a los nacionalistas españoles, o hay un nacionalismo español en el movimiento? ${ }^{34}$ Ya Carrillo empleo el mismo recurso para ser aceptado por la sociedad española de la Transición introduciendo en sus discursos la palabra España e incluyendo en sus estrados la bandera cuando ambas era parcela casi exclusiva de la derecha ${ }^{35}$; quizá sea por esto

32 J. F. García Santos, Léxico y política de la Segunda República, Studia Philologica Salmanticensia, Salamanca, 1980.

${ }^{33}$ Hemos de considerar la Dictadura del General Franco como un paréntesis en cuanto al uso de un lenguaje político activo dada la ausencia de oposición política durante esos años.

${ }^{34}$ De acuerdo con Olloqui (J. Olloqui, «La patria en el discurso político de Pablo Iglesias: la construcción del concepto de patriotismo constructivo a través del lenguaje metafórico», en Cuadernos de investigación filológica, 42, 2016) el patriotismo se define como «una de las formas más importantes de cohesión grupal en el mundo contemporáneo. Su apelación persuasiva al orgullo nacional y el espíritu de unidad colectiva cubre ciertas necesidades psicológicas de determinados grupos sociales al proporcionar a sus miembros un sentimiento de pertenencia a una comunidad. Este sentimiento, a su vez, satisface el deseo de conexión y afiliación social así como la necesidad de seguridad y protección». La cuestión es que el término «patria» que emplea Podemos no es la «patria» de la que habla la derecha. Se aprovecha del término para buscar esa transversalidad que se propone, pero su concepto de patria es otro. Es la diferencia que existe entre los teóricos de la política entre el «patriotismo ciego» y el patriotismo constructivo». «Blind versus constructive patriotism: Moving from embeddedness in the group to critical loyalty and action», en Patriotism in the lives of individuals and nations (ed. de D. Bar-Tal \& E. Staub), Nelson-Hall, Chicago, 1997, págs. 213-228). «El patriotismo ciego se caracteriza por el apoyo incondicional a la patria, una actitud rígida donde no hay espacio para la crítica». Mantienen actitudes sumisas a los líderes, reafirma los valores tradicionales, rechaza la multiculturalidad y la inmigración, se preocupan más por cuestiones relacionadas con la seguridad y la protección de la cultura nacional. En cambio, «el patriotismo constructivo es definido como el apego y la consideración al bienestar de los miembros del grupo propio con una actitud inclusiva hacia el resto de seres humanos respetando sus derechos y libertades, algo que Staub (1989) describe como lealtad crítica». Su actitud es a menudo discordante hacia los líderes, es más social, cuestiona los valores tradicionales, se preocupa del bienestar de todas las personas etc. Ambas vertientes son patrióticas en tanto en cuanto ambas están basadas en sentimientos de apego y afecto por la patria». Es en este sentido en que se emplea patria en el discurso de Pablo Iglesias: «La patria es la gente» (El Confidencial, 12-10-2016).

${ }^{35}$ En el caso de Podemos, parece más bien un intento de atraer a parte de la población que comulga con la presencia de la bandera en un intento de abrir el abanico de ciudadanos que elijan su opción política:

La dirección del partido y una buena parte de sus simpatizantes quieren normalizar la relación con la bandera de España y que ésta esté presente en sus actos. La idea es asumirla 
o quizá sea por el convencimiento patriótico propio del populismo que relata Charaudeau ${ }^{36}$.

El Discurso para la Presidencia del Parlamento Europeo, efectivamente, marca la línea del discurso político de Pablo Iglesias que, meses después, continúa con el mismo léxico y la misma estrategia. El 18 de octubre de 2014 hablaba en la Plaza de Vistalegre ante la asamblea fundacional de la formación, según recoge el diario El País, en estos términos:

Existe una mayoría social, dijo, «que quiere que los ricos paguen impuestos, que sabe que la única manera de acabar con la corrupción es democratizar la economía, y que sabe que el problema de la crisis es que hemos estado gobernados por mangantes».

Iglesias arremetió desde el escenario del Palacio de Vistalegre, en Madrid, contra los «partidos de la casta», nombrándoles abiertamente. «Dijimos patria y nos criticaron. Dijimos que los que quieren romper España son los que tienen cuentas en Suiza o Andorra, sean de ciu, PP o Partido Socialista», subrayó antes de hacer un guiño a las clases medias en contraposición con el actual sistema de representación democrática. «Sentirnos orgullosos de este país es sentirnos orgullosos de las mejores escuelas públicas, de los mejores hospitales... No es la casta política la que hace funcionar este país, es la gente, esa es nuestra patria, la gente».

como un símbolo despojado de connotaciones políticas del franquismo, la derecha o el modelo de Estado.

Tal y como publica 'El Mundo', miembros de la cúpula de Podemos consideran que la relación de la población con la bandera es más «natural» que la que guardan algunos partidos de izquierdas. «Estoy deseándolo [ver la bandera en los actos], pero nuestra gente se resiste, no lo ve muy claro», dice un influyente dirigente de la formación, que admite la dificultad de cambiar esa mentalidad entre las bases.

Después de evolucionar en el terreno de la moderación en algunas propuestas, para reivindicar su sitio en el espacio abandonado por el PSOE, Pablo Iglesias ha roto estereotipos - $\mathrm{O}$ léase complejos - de la izquierda más clásica. Así, en sus mítines ha despatrimonializado de la derecha palabras como «patria» - reformulando su sentido para definirla como «la gente» y no como un espacio territorial - o ha alabado a los profesionales del Ejército, la Policía y la Guardia Civil (Lavozlibre.com, 27-04-2015).

${ }^{36}$ Las declaraciones del líder de Podemos tras la visita del Papa Francisco al Parlamento Europeo (25-11-2014) pueden plantearse desde la misma perspectiva de interpretación: convicción, estrategia o ambas. El twitter de Pablo Iglesias recogía expresiones como:

Un Papa «útil para la gente de abajo». Y un Papa interesante «cuando denuncia el escándalo de los poderes financieros que están secuestrando la democracia». «Estamos en desacuerdo con algunas cosas, pero hay que aplaudir la valentía de Jorge Bergoglio, capaz de decir algunas cosas que cuando decimos nosotros se nos acusa de populistas». «El programa económico del Papa es el de @ahorapodemos». «Interviene el Papa en la eurocámara. Defiende los derechos humanos y sociales como base de la dignidad. Bravo».

En su día, los comunistas hicieron lo propio:

El concepto de cristiano y el de comunismo no se pelean entre sí. Y desde mis profundas convicciones de católico practicante, pongo a Dios por testigo de que lo que digo es verdad (G. Morán, El País Semanal, 25-II-79). 
«El cielo no se toma por consenso. Se toma por asalto» ${ }^{37}$ (El País, 1910-2014).

«Podemos es el instrumento de la gente de abajo para la ruptura con el régimen»/Clara Marañón, de Construyendo Pueblo, durante la defensa de su propuesta política, el domingo.

- «Somos protagonistas de nuestra historia, somos el cambio; es nuestro momento» / Iñigo Errejón, durante la defensa de su documento político, Claro que Podemos, el domingo.

- «Hoy nace una nueva fuerza política para cambiar El País, ¡claro que podemos!»/ Pablo Iglesias, en la clausura del primer encuentro presencial de la asamblea de Podemos, el domingo (Público, 19-10-2014). En palabras de Iglesias, Podemos es una «alternativa frente a un régimen que se derrumba», en referencia al PP, al PSOE y al pacto constitucional. «Podemos no es un experimento político, Podemos es el resultado del fracaso del régimen de oligarcas». «Podemos no es un experimento político, Podemos es el resultado del fracaso del régimen, de sus oligarcas, de esos viejos de corazón. Pues bien, la gente les ha respondido: claro que podemos» (El País, 16-11-2014).

En Podemos «hay puertas abiertas, en el cambio no sobra nadie, basta con amar tu patria que no es una bandera, son los hospitales públicos, los colegios y las ayudas para quienes las necesitan» (Lavozlibre.com, 21-05-2015).

Los ricos, la patria, la casta, la gente, la ruptura, el régimen, términos antiguos que se rejuvenecen a la sombra del nuevo partido político.

Así pues, la selección léxica y un esquema narrativo-argumentativo claro cumplen una estrategia política para llegar a un público que comprenda con facilidad partiendo de la simplificación metafórica de «La política es una batalla» ${ }^{38}$, donde los antagonistas son el rico y el político confabulados para buscar su propio beneficio en contra de los derechos del pueblo, y donde existe un héroe que representa los nobles valores de igualdad, libertad y fraternidad. El esquema narrativo es claro, y la selección léxica acompaña a este discurso maniqueo canónico que deprende cierto aroma a antiguo por la selección de los términos que emplea, un lenguaje propio de la retórica de la izquierda que conforma un relato próximo a la épica de la revolución de los pueblos. Dicha selección léxica ${ }^{39}$ pretende revivir marcos cognitivos propios de otros momentos de la historia para alentar reacciones propias de esos momentos concretos:

${ }^{37}$ La expresión la utilizó Marx en una carta que dirigió a su amigo el doctor Kugelmann el 12 de abril de ese año y se convirtió en una referencia relativamente frecuente en la retórica comunista. Irene Falcón, secretaria de Dolores Ibarruri 'Pasionaria', tituló precisamente Asalto a los cielos su libro de memorias, publicado en 1996 (B. Marín, El País, 18-10-2014).

${ }_{38}$ G. Lakoff y M. Johnson, Métaforas de la vida cotidiana, Cátedra, Madrid, 1986.

${ }^{39}$ Estas fueron las palabras más empleadas en su discurso (eliminamos preposiciones, determinantes, conjunciones, etc.):

Europa/europea: 18; Pueblo/pueblos: 13; Nos, nuestro, nuestra: 11; Hoy: 8; Amenazar: 7; Parlamento: 5; Todos/as: 5; Soberanía: 4; Deuda: 4; Lucha: 3. 
Europa volvió a despertar en la resistencia de sus pueblos contra el fascismo, en los supervivientes de los campos de exterminio, en quienes dieron su vida por la justicia y la libertad (P. Iglesias, Discurso para la Presidencia del Parlamento Europeo, 30-06-2014).

Pero la selección léxica, el maniqueísmo y la narratividad como técnicas para estimular un determinado marco cognitivo no son exclusivas del populismo, sino que son propias de todo discurso político. Ahora bien, lo que es propio del populismo como discurso es una selección léxica de términos negativos extremos y una narración épica como la que presenta Pablo Iglesias en su discurso a la presidencia del Parlamento Europeo. En este caso, el enemigo no es uno, son todos; la actitud del líder es más la de un héroe patriota que se enfrenta a todos y los argumentos que emplea responden a las expectativas del pueblo, independientemente de que sean realizables o no. Esto es lo que caracteriza el detalle del discurso populista.

Se puede practicar el populismo de forma puntual, determinados partidos pueden tener pequeños brotes populistas para solucionar cuestiones concretas dando pábulo a las reclamaciones del pueblo (recordemos el cheque bebé del expresidente del gobierno español, Rodríguez Zapatero [2004-2011]), pero ningún partido en España responde a la acumulación de marcas populistas que sí responden Chávez, Maduro, Le Pen, etc. Hay un populismo genérico y hay un populismo puntual y, entre ellos, distintas gamas de populismo; hay populismo frente a propuestas populistas. En definitiva, como bien apuntaba Charaudeau, habremos de reconocer populismos diferentes de acuerdo con las circunstancias del momento. El discurso de Podemos es, evidentemente, durante los primeros meses de aparición ${ }^{40}$, populista, pero menos populista que el de Chávez, ya que acumula menos características definidoras de dicho discurso ${ }^{41}$.

De lo que no cabe la menor duda es que es un discurso perfectamente estudiado que sigue a la perfección los cánones del género; es un discurso maniqueo y emocional; es un discurso que cumple casi a rajatabla con las normas que impone la retórica del discurso deliberativo. Partimos de un exordium como parte inicial de su discurso donde trata de conseguir la atención, la docilidad

${ }^{40}$ A de diciembre de 2014, cuando aparecen las primeras encuestas donde se reconoce a Podemos como primera fuerza política del estado español en intención de voto, el discurso empieza a moderarse.

${ }^{41}$ De hecho, intentan por todos los medios alejarse de la posible identificación con el modelo chavista:

Íñigo Errejón ha querido aclarar, por otro lado, que Podemos no tiene por intención trasladar a España las políticas de los Gobiernos de Chávez y Maduro en Venezuela, un país, ha asegurado Errejón en la conversación digital, que «no es un modelo para España». «La situación de Venezuela depende en primer lugar del voto de sus ciudadanos, que son soberanos. Les corresponde a ellos decidir», ha reflexionado el investigador de la Complutense, que ve en la vinculación de la formación con Venezuela una «burla a la ciudadanía española» que busca «generar miedo» (El País, 13-11-2014). 
y la benevolencia del público (iudicem benevolum, docilem, attentum parare), una narratio donde realiza comunicación interesada de los hechos al auditorio, presentándolos de la manera más favorable posible para el orador ${ }^{42}$, etc.

Si leemos el discurso de Pablo Iglesias no es muy difícil observar cada una de estas partes. La llamada a una respuesta emocional es evidente ${ }^{43}$. Todo el discurso pretende mover al auditorio hacia una disonancia cognitiva que pueda provocar un voto en favor de las posturas del orador al sentir la culpabilidad por el panorama desolador que presenta ${ }^{44}$, disonancia que puede negociarse votando a Pablo Iglesias como Presidente del Parlamento; apela al gregarismo mostrando un sentimiento de unión y unanimidad de los pueblos apoyado por un constante uso del nosotros y del pueblo que aporta esa sensación de unanimidad que insta a seguir al grupo; emplea hábilmente lo que en política se denomina el efecto underdog, el sentirse víctimas de las circunstancias, sometido por un gobierno y unas oligarquías financieras que abusan de su poder. El político es plenamente consciente de la corriente de simpatía que puede suscitar en el ciudadano aquel que se encuentra maltratado por el poder. Es humano estar del lado del débil. En caso contrario, se crea disonancia. Puro marketing político que en ningún momento sus dirigentes ocultan que es fruto del trabajo, del estudio y de horas de reflexión retórica y política que está muy lejos de la improvisación. La mayoría de los miembros dirigentes de Podemos son profesores universitarios, y no pueden evitar hacer docencia de su propia estrategia política ${ }^{45}$.

Como señalaba el historiador José Álvarez Junco (El País, 11-10-2014) «aunque los dirigentes populistas se proclamen anti-políticos y exijan que el poder - hoy en manos de políticos profesionales - retorne al pueblo, ellos también

${ }^{42} \mathrm{La}$ argumentatio es la parte racional y central del discurso. Consta de probatio (en la que se defiende la propia postura del orador) y refutatio (destinada a rebatir los argumentos de la parte contraria), y viene preparada por el exordium y la narratio (que en cierto sentido es ya una probatio en forma narrativa).

La peroratio, parte final del discurso, tiene dos finalidades: recordar sucintamente lo ya expresado (recapitulatio) e influir emotivamente (affectus) en el auditorio. La moción de sentimientos, por lo tanto, es importante en el exordium, pero es más importante aún en la peroratio, y se ha de procurar especialmente al final del discurso, porque su efecto, aunque intenso, es de corta duración, y el juez o el auditorio han de estar condicionados emocionalmente a la hora de toma de decisión.

La peroratio del género judicial consta de la indignatio, en la que se intenta indisponer totalmente al público contra la parte contraria, y de la conquestio, mediante la cual se intenta lograr la simpatía del juez a través de la compasión que pueda despertar la injusticia sufrida o la desgracia que nos amenaza (A. Martínez Jiménez, «La retórica clásica y la neurociencia actual. Las emociones y la persuasión», en Rétor, 4/1, págs. 56-83).

${ }^{43} \mathrm{Su}$ despedida en el debate televisado las elecciones de diciembre de 2015 es una prueba evidente: «Sonrían, sí se puede» (La sexta, 8-12-2015).

${ }^{44}$ Realmente, el discurso va más dirigido a la prensa, que hará de vocera del mismo para que lo consuman posibles electores que a los propios parlamentarios. Pensar en que un representante de un grupo determinado no va a respetar la disciplina de voto es una ilusión.

$45<$ https://www.youtube.com/watch?v=Yizw-RySZnI $>(20-11-2014)$. 
son políticos», y por el estudio del análisis de su discurso que acabamos de ver, no cabe la menor duda ${ }^{46}$.

El discurso de Podemos es, pues, hasta la fecha, un discurso eminentemente retórico, deliberativo, político, que, independientemente de que los contenidos que propone puedan ser o no llevados a cabo, cumple con el esquema general del discurso populista, cumple con los esquemas del discurso político y maneja con eficacia las estrategias propias del género, aunque no se reconozca en ciertos argumentos y actitudes del líder un populismo canónico.

Hasta ahora, y en lo que se refiere a su lenguaje, indudablemente distaba mucho de estar en la «centralidad del tablero» que proponen (El País, 18-102014) ${ }^{47}$, estrategia que ya empleo el PSOE en la Transición española a la democracia tras la dictadura del General Franco. De hecho, el cambio ${ }^{48}$ es uno de los leit motiv de Podemos como lo fue (Por el cambio) en el PSOE de $1982^{49}$. Algunos comentaristas políticos ya comparan ambos discursos (Joaquín Estefanía, El País, 10-11-2014) y señalan, por ejemplo, que «La CEOE acusó al PSOE de aproximarse a los modelos marxistas de Europa del Este», al igual que se acusa ahora a Podemos de acercase a los gobiernos populistas latinoamericanos: mutatis mutandis. Lo cierto es que, al igual que hizo el PSOE moderando su lenguaje, su programa y su ideología ${ }^{50}$, Podemos empieza a seguir el mismo

${ }^{46}$ En su página web (podemos.info), se lee: «Podemos no es, ni quiere ser, un partido político», pero está registrado formalmente como tal desde el 11 de marzo de 2014. (F. Moreno Fernández, op. cit., pág. 73).

${ }^{47}$ El 3 de octubre de 2015 (El País) continúa el mismo discurso:

«Nuestros adversarios», escriben Iglesias y Errejón, «quieren encajonarnos en el margen izquierdo del tablero y encerrarnos a hablar de nosotros mismos. Nosotros seguimos sabiendo que los de arriba no tienen proyecto para el país real y que nuestras ideas son de sentido común, transversales y transformadoras».

${ }^{48}$ El 25 de abril de 2015, Pablo Iglesias publicaba un artículo en El País titulado ¿Qué es el cambio? En él, abrazaba con entusiasmo la economía socialdemócrata a la vez que se hacía abanderado del cambio frente al recambio que proponían otros. En este artículo ya abandona con claridad el lenguaje que le había caracterizado hasta ese momento.

Hace poco me reuní en Madrid con 'Economistas Frente a la Crisis' (EFC), un grupo plural e independiente de economistas, muchos de cuyos miembros proceden de la tradición socialdemócrata. No tienen ninguna intención de vincularse con partido alguno, pero sí de que sus propuestas sean asumidas por las formaciones políticas progresistas de nuestro país. Tras leerlas con atención y escucharles les dije que para mí sería un honor llegar a acuerdos y formar parte de un Gobierno que asumiera tales propuestas. Precisamente porque señalan las claves del cambio político en nuestro país, que pasan por señalar que las políticas económicas aplicadas hasta ahora han sido un desastre y que es necesario rectificar.

${ }^{49}$ No es nada original, por otra parte la introducción de tal término. Ana Mancera y Ana Pano (El discurso politico en Twitter, Anthropos Editorial, Barcelona, 2013) han mostrado el uso continuado del concepto de «cambio» desde las elecciones de 1982 hasta 2011. En el 2015, seguimos..., obviamente, este uso constante muestra una efectividad evidente.

${ }^{50}$ Las declaraciones de los socialistas de la época son ciertamente esclarecedoras, tanto en lo que se refiere al marxismo:

«Yo soy marxista en el sentido de que acepto la ideología marxista como método para transformar la sociedad» (F. González, Interviú, 26-VIII-76). 
camino ${ }^{51}$. De hecho, Pablo Iglesias declaraba el día de la presentación de su Programa económico para la gente que «las propuestas que asumimos son las que hasta no hace mucho tiempo iba a asumir cualquier socialdemócrata» (El Pais, 28-11-2014)52, y renunciaba expresamente al impago de la deuda, a la jubilación a los 60 años o a la propuesta de renta básica universal que habían sido los elementos fundamentales, todos ellos tildados de populistas, del programa de Podemos al parlamento europeo. Con el paso de los días, la definición del discurso se hace más clara:

P. ¿Por qué Podemos ha abandonado ideas consideradas radicales?

R. Hay una cosa que es verdad. No es lo mismo hacer un programa para unas elecciones europeas, en el que se definen una serie de características generales de cómo está la situación en Europa, «que hacer un programa de Gobierno para gobernar», y es verdad que se nos ha puesto

«Yo desearía que en nuestro próximo congreso desapareciera el término marxista» (F. González, La Calle, 16-V-78).

«El socialismo no puede ser igual al marxismo» (F. González, El País, 13-VI-78).

«Si queremos llegar a transformar la sociedad, hemos de llegar al poder y para ello necesitamos ocho millones de votos. No tenemos más remedio que ampliar nuestra base hacia la derecha» (F. González, YA, 10-V-80).

Como al socialismo:

«En realidad un partido socialista ha de englobar un espectro social muy amplio, desde posiciones socialdemócratas consecuentes hasta el socialismo más radical» (F. González, Cambio 16, 9-15-XI-76).

«En sus casi cien años de existencia, es constante en el PSOE la tendencia dialéctica entre concepciones socialdemócratas y marxistas» (F. González, Triunfo, 13-V-78).

«No hay diferencia fundamental entre socialismo y socialdemocracia...» (E. Múgica, $L a$ Calle, n. 8, 16-22-v-78).

«La socialdemocracia no es más que el fruto de la evolución de la clase trabajadora» (F. González, YA, 10-V-78).

«No tengo inconveniente en ser llamado socialdemócrata» (F. González, La Calle, no. 8, $16-22-\mathrm{V}-78)$

${ }^{51}$ Y la izquierda, buscando recuperar los votos perdidos en favor de Podemos lo hacen evidente:

El coordinador general de IULV-CA, Antonio Maíllo, ha criticado este lunes «el giro de derechización» que está sufriendo Podemos, toda vez que considera que «cada vez hay más parecido» entre el líder de la formación 'morada', Pablo Iglesias, y el expresidente socialista Felipe González: «hay gestos y actitudes claras de modulación de su mensaje, que no es lo que pretendían ser». «Desde la izquierda hacemos el diagnóstico de proyectos políticos que vendían una cosa y hacen otras», ha manifestado.

En este sentido, ha afirmado que Iglesias, con «gestos para ser respetable», le recuerda «cada vez más» a Felipe González. «Ha hecho el mismo camino que el expresidente en tres meses» (Lavozlibre.com, Europa Press, 27-04-2015).

52 El propio expresidente del gobierno, José Luis Rodríguez Zapatero apoyaba, sorprendentemente, esta idea:

El expresidente del Gobierno español y exlíder del PSOE José Luis Rodríguez Zapatero cree que Podemos no es «populista» sino más bien «socialdemócrata» (ABC, 23-03-2015). 
el gesto serio. Lo que nos han dicho los economistas con los que hemos trabajado es que no vamos a poder reducir la jubilación a 60 años en un año ni en dos, tiene que ser una tendencia para repartir el trabajo pero nos lo tenemos que plantear como tendencia.

P. ¿Y con la renta básica?

R. Nos han dicho también que aunque la renta básica es una magnífica idea y una tendencia muy interesante, no lo vamos a poder hacer en los dos primeros años.

P. ¿Están entonces haciendo un programa más realista?

R. Es evidente que cuando tienes responsabilidades de Gobierno y vas a tener que negociar con sectores muy poderosos claro que se nos endurece el gesto.

P. «Usted defiende que el programa de Podemos es socialdemócrata», pero Izquierda Anticapitalista es la base de la formación y está marcada ideológicamente.

R. Creo que las definiciones ideológicas sirven mal para entender la situación actual.

P. ¿Y para hacer un programa electoral, entonces?

R. Creo que la ideología que puede tener cada uno puede ser un elemento que defina identidades, pero a la hora de hacer un programa de Gobierno hay que ver las condiciones de posibilidad. La socialdemocracia históricamente planteó una serie de cuestiones que tenían que ver con los derechos sociales. Y algunos reconocían que estaban bien, incluso la democracia cristiana. A quien piensa que con izquierda y derecha se puede entender el espacio político de nuestro país nosotros decimos que es un juego de trileros.

(P. Iglesias, El País, 18-01-2015)

Además, apela abiertamente al mismo espíritu que llevó al cambio socialista en el año 1982:

Pablo Iglesias llevó este sábado «su principal meta estratégica a Andalucía». El líder de Podemos aplicó a esa comunidad, «feudo del poder institucional del PSOE», un llamamiento al voto de las generaciones que durante la Transición fueron determinantes para la victoria de Felipe González. La formación busca hacerse con el espacio político que tradicionalmente han ocupado los socialistas y, en este contexto, Iglesias apeló en Málaga a los «abuelos y abuelas que se han partido la espalda trabajando para que sus nietos no tengan que emigrar» (El País, 14-03-2015).

El discurso político populista deja paso al discurso puramente político. De nuevo se impone la consecución del poder a la ideología.

Lo curioso es que, cuando modera su mensaje para intentar abarcar el mayor abanico posible de votantes y tocar el poder, los daños colaterales son evidentes: la intención de voto cae estrepitosamente; de ser la primera fuerza política pasa a colocarse en cuarto lugar perdiendo un amplio porcentaje de votos: 
Juan Carlos Monedero, uno de los fundadores e ideólogo de Podemos, deja el partido con amargas críticas al grupo:

[...] en el momento en que las fuerzas políticas tienen como principal objetivo «acceder al poder», entran también «en el juego electoral y empiezan a ser rehenes de lo peor del Estado, de su condición representativa» (El País, 30-04-2015).

Y el grupo político que había ido abandonando paulatinamente el populismo, vuelve al discurso que le había dado el éxito, el discurso agresivo, insultante, porque la gente necesita catarsis, necesita una vía para canalizar el hartazgo y la desafección ${ }^{53}$ :

«La corrupción es una forma de gobierno. Se lo vamos a decir a la condesa de sangre azul, corrupta, gentuza, corruptos, ladrones. Ellos dicen que quieren echar de Madrid a la gente sin hogar...la gente quiere echarles a ellos», ha lanzado antes de explicar la filosofía de redistribución de la riqueza que plantea el programa marco de la formación, en las antípodas, en su opinión, del proyecto de Albert Rivera. «Yogur de color azul, yogur de color naranja: son lo mismo. El cambio no es utopía», ha agregado (El País, 8-05-2015).

El líder de Podemos ha vuelto a cargar contra el jefe del Ejecutivo, a quien ha calificado de una «maldita avestruz» [...] «Ustedes, señor Rajoy, son mayordomos de los ricos». [...] «No nos gustan los pijos. Mentirosos, hipócritas, miserables... La democracia no la trajeron los pijos», ha enfatizado (El Pais, 16-05-2015).

\section{Como señalaba Monedero, ideólogo de Podemos:}

La moderación desarmaría a Podemos. Lo peor que le puede pasar es que cuando hable algún líder se sepa de antemano lo que va a decir [...] las clases medias [...] necesitan lo que les ha dado Pablo y lo que Pablo ha empezado a volver a dar: herramientas de indignación frente a gente que nos está arañando.

P. ¿Está rectificando la actitud Pablo Iglesias?

R. Sin duda. Creo que mi salida de la dirección sirve para que haya una reacción (El País, 14-05-2015).

\footnotetext{
${ }^{53}$ Curiosamente, se llega a un equilibrio entre un lenguaje agresivo y una política que se centra en la recuperación del voto socialista de la transición. Ideológicamente, pues, se modera el discurso, pero con un lenguaje que sigue las mismas pautas que llevaron al partido a posiciones electorales de poder: «Los socialistas de corazón saben que el día 24 tienen que votar morado», ha proclamado. "Vengo de una familia socialista», ha proseguido el líder de la formación para rememorar la «ilusión» de su abuelo, que en 1982 votó a Felipe González, y que vivió una decepción apenas cuatro años después (El Pais, 16-05-2015).
} 
De nuevo se impone la consecución del poder a la ideología. O ya no se sabe dónde está la búsqueda del poder y dónde queda la ideología ${ }^{54}$.

\section{ANEXO}

\section{Discurso de Pablo Iglesias en el Parlamento Europeo (30-06-2014)}

1. Es un honor dirigirme a ustedes para presentar mi candidatura a la presidencia de esta cámara. Este parlamento está llamado a representar la soberanía de Europa y debemos, señorías, estar a la altura de lo que ello significa hoy.

2. El sueño de Europa ha sido sepultado muchas veces pero siempre consiguió despertar de nuevo. Así sucedió hace casi 70 años: Europa volvió a despertar en la resistencia de sus pueblos contra el fascismo, en los supervivientes de los campos de exterminio, en quienes dieron su vida por la justicia y la libertad. Millares de compatriotas míos, que habían luchado defendiendo la democracia en España, participaron en esa lucha y en ese sueño de justicia. No se imaginan el orgullo que me produce como español que los primeros tanques que entraron a liberar Paris fueran guiados por combatientes españoles. Hoy, cuando la intolerancia y la xenofobia vuelven a amenazarnos, quiero reivindicar la memoria europea del antifascismo y la de todos los pueblos amantes de la libertad y la democracia.

3. Señorías, lo mejor de nuestro continente y de nuestra historia común se forjó en las revoluciones que hicieron al pueblo sujeto de derechos, por encima de reyes, de dioses, de nobles y de grandes propietarios. El mejor patrimonio de Europa es la voluntad de sus ciudadanos de ser libres y no ser siervos de nadie. No ser siervos de nadie, señorías, eso es la democracia.

4. Por eso hoy debo decirles que los pueblos a los que debemos las libertades y los derechos sociales no lucharon por una Europa en la que sus gentes vivan en el miedo a la pobreza, a la exclusión, al desempleo o al desamparo frente a la enfermedad. La expropiación de la soberanía y el sometimiento al gobierno

${ }^{54}$ En los primeros meses del curso político de 2016 arrecia la discusión sobre la dirección del discurso político de Podemos. O bien se modera el discurso (Errejón) o bien se radicaliza (Iglesias) para recuperar los votos perdidos. En un cruce de twits aparece toda la dinámica de la confrontación en el interior del partido:

Errejón: «A los poderosos ya les damos miedo, ese no es el reto. Lo es seducir a la parte de nuestro pueblo que sufre pero aún no confía en nosotros».

Iglesias: «Sí compañero @ierrejon pero en Junio dejamos de seducir a 1 millón de personas. Hablando claro y siendo diferentes seducimos más».

Pocos meses antes (25-07-2016) El Confidencial recogía que «La hipótesis populista forma ya parte de un ciclo que Podemos ha dado por cerrado», y en octubre, todavía Iglesias insiste: «'El gran debate, lo que tenemos que discutir en estos meses' es si Podemos tiene que seguir siendo populista o no» (El País, 6-10-2016). Lo curioso es que el propio Iglesias acusa a Rivera de populista en el debate de investidura de Mariano Rajoy (27-10-2016). La estrategia política se impone a la ideología. 
de las élites financieras, amenazan el presente y el futuro de Europa, amenazan nuestra dignidad, amenazan la igualdad, la libertad y la fraternidad, amenazan nuestra vida en común. La creación de nuevas instancias supranacionales no tiene que pagarse al precio de incapacitar a la ciudadanía. Nuestros pueblos no son menores de edad, ni colonias de ningún fondo de inversiones, no conquistaron y defendieron su libertad para entregársela a una oligarquía financiera. No son términos abstractos, señorías, todos ustedes conocen bien el problema. Es escandalosa la facilidad con que se mueven aquí los lobbies al servicio de grandes corporaciones así como las puertas giratorias que convierten a los representantes de la ciudadanía en millonarios a sueldo de grandes empresas. Hay que decirlo alto y claro: esta manera de funcionar hurta la soberanía de los pueblos, atenta contra la democracia y convierte a los representantes políticos en casta.

5. Señorías, la democracia en Europa ha sido víctima de una deriva autoritaria. En la periferia europea la situación es trágica: nuestros países se han convertido casi en protectorados, en nuevas colonias, donde poderes que nadie ha elegido están destruyendo los derechos sociales y amenazando la cohesión social y política de nuestras sociedades.

6. De América Latina aprendimos que la deuda externa está diseñada para ser impagable, y que los países que más han crecido lo hicieron con una quita sustancial y una auditoría pública de su deuda. Todos conocen en esta cámara la deuda perdonada hace no tanto tiempo a Alemania. No es sólo una cuestión de justicia, tiene que ver con la integración europea y con la democracia: la deuda es hoy un mecanismo de mando y saqueo de los pueblos del sur. Eso es lo que está sucediendo en esos países que, con marcado racismo, algunos denominan PIGS. Pero supongo que son ustedes conscientes de que no hay Europa sin sus pueblos del Sur, como no la hay sin sus pueblos del Este, sometidos también a duras condiciones de la Troika, cuyo rumbo amenaza con destruir el proyecto europeo dejando un rastro de miseria, pobreza y violencia.

7. Pero hay otro camino. Hay alternativa a las políticas de empobrecimiento y al secuestro de la soberanía. Este Parlamento, en esta hora crítica para Europa, debe estar a la altura, debe demostrar sensibilidad y convertirse en el epicentro de una sacudida democrática en la Unión Europea, una sacudida que frene la deriva autoritaria de la Troika. Este Parlamento debe expresar la legitimidad democrática de origen que a todos nos reúne, la voz de los ciudadanos, y no los arreglos entre élites. El Parlamento Europeo no puede ser un premio de consolación, ni una jubilación dorada.

8. Señorías, hoy yo no me dirijo a una cámara de cinco, seis o siete grupos parlamentarios. Tampoco me dirijo a las maquinarias de partido. Me dirijo a ustedes, señoras y señores eurodiputados, porque ustedes tienen un contrato de responsabilidad política firmado con sus pueblos. Me dirijo a los demócratas y a sus conciencias. Nuestra primera fidelidad, a la que todas las demás deben supeditarse, es con los ciudadanos que nos han elegido. Ellos no están en los pasillos de este edificio, ni en los hoteles que rodean esta cámara. Pero recuerden: 
ellos son los soberanos y tarde o temprano pedirán cuentas de lo que se ha hecho en su nombre.

9. Me dirijo también y muy especialmente a mis colegas eurodiputados de los países del sur de Europa. Ustedes han visto las consecuencias reales que tienen las políticas impuestas por la Troika. Ustedes saben que las políticas de austeridad han fracasado: nuestros países son hoy más pobres, con economías destruidas, con sociedades heridas de injusticia e instituciones cuarteadas por la corrupción y el descrédito. Ustedes saben que es hora de ayudar a nuestros países a ponerse de nuevo en pie. Les pido que al menos hoy voten como griegos, como irlandeses, como portugueses, como italianos, como checos, como polacos, como rumanos, como españoles. No sólo para que puedan mirar a la cara a su gente cuando vuelvan a casa, sino porque así estarán defendiendo Europa. Les pido su voto consciente de que muchos de ustedes no comparten este secuestro de la democracia, sabiendo que muchos de ustedes están sinceramente comprometidos con el bienestar de sus pueblos. Les pido el voto para frenar a la gran coalición que impone la austeridad y el totalitarismo financiero.

10. Quiero dirigir mis últimas palabras a la ciudadanía y a los pueblos de Europa que han salido a la calle en estos años para defender justicia social y la democracia. A los millones que habéis dicho basta en las plazas europeas, quiero deciros que sois el orgullo, el corazón democrático de Europa. Mantened alta la bandera de la dignidad. Los pueblos de Europa hemos pasado por peores situaciones y nos hemos sacudido a los déspotas. No sé si hoy podremos arrebatarle la presidencia de este parlamento a la gran coalición pero si nos seguís empujando os aseguro que venceremos. El mañana es nuestro.

\section{BIBLIOGRAFÍA}

ARISTÓTeles, Retórica, Madrid, Gredos, 1990.

Bruner, J., Actual minds, possible worlds, Harvard University, Cambridge, 1986.

Müller, J., \#Podemos. deconstruyendo a Pablo Iglesias, Deusto, 2014.

SAntiago Guervós, J. DE, Principios de comunicación persuasiva, Arco/Libros, Madrid, 2005.

SANTIAGO GUERVÓs, J. DE, «La selección léxica en la comunicación persuasiva: manipulación y uso del significado para la descodificación y la inferencia», Español Actual, 89, 2008, págs. 111-122.

VAN DiJK, T. (ed.), El discurso como interacción social, Barcelona, Gedisa, Barcelona, 2000. 
